\title{
22 \\ Connecting with Lapita in Vanuatu: Festivals, sporting events and contemporary themes
}

\author{
Richard Shing and Edson Willie
}

\begin{abstract}
Lapita research in Vanuatu has played a significant role in the greater understanding of the deep history of the wider Pacific. A number of recorded sites from the archipelago are known by a global academic audience, particularly the Teouma site located on the central island of Efate. The Vanuatu Cultural Centre has played a key role in the research aspect, but it also has a specific responsibility in disseminating information and connecting local communities to the investigations. This has been undertaken often through standard media channels, but there have also been some unexpected directions that have been generated. Here we outline the development of an annual Lapita Festival held since 2015 and its extension to a major sporting event that took place in Vanuatu in 2017.
\end{abstract}

\section{Introduction}

Lapita plays a very significant role in the understanding of Vanuatu's history. As the initial founding population in this part of the world, and being our ancestors and the ancestors of much of the Pacific that we know today, the knowledge gleaned from studying and researching the Lapita people is vital in understanding who we are today and why, despite having diverse cultures, there are many similarities that tie the whole of Oceania together.

Archaeological research on Lapita has been ongoing in the Pacific region since the 1950s and has contributed greatly to shedding light on the prehistory of the people of the Pacific. In Vanuatu, Lapita was first identified in the 1960s through surface surveys on Efate and Malo (Hébert 1965; Hedrick and Shutler 1969), but more detailed research and the number of Lapita sites really only started gaining momentum from the early 2000s. Research and training programs in the north, primarily focusing on the smaller offshore islands of Malakula and Santo, were associated with the discovery of some very well-preserved Lapita sites, particularly on the islands of Vao and Uripiv, off the north-east coast of Malakula (Bedford 2003, 2006) and the Makue site on Aore Island, south Santo (Noury and Galipaud 2011). However, the site that was to really transform our understanding of Lapita and provide a whole series of opportunities for its promotion and wider understanding among the Vanuatu community was that of Teouma, found in early 2004, and the subsequent excavations that were carried out at the site (2004-2006, 
2008-2010) (Bedford et al. 2010b; Shing 2013). Other Lapita sites have also been found since Teouma, including on the island of Mota Lava in the far north and on Aneityum in the far south (Bedford and Spriggs 2014; Bedford et al. 2016). Lapita sites have now been found across almost the full stretch of inhabited islands of the archipelago with only the Torres Islands in the very far north yet to reveal any Lapita occupation.

While the academic side of the research has generated spectacular results that attract worldwide interest, the Vanuatu Cultural Centre-Vanuatu Kaljoral Senta (VCC or VKS) has a key role in disseminating information to local communities and schools across our archipelago. A whole range of activities, over many years, has been designed to raise awareness among the wider community. The various activities have mostly been developed independently and separately depending on the availability of resources, their suitability and taking advantage of various key opportunities (Bedford et al. 2011; Shing 2013).

Such an opportunity presented itself in 2015, when Vanuatu hosted the Eighth Lapita Conference, which generated both significant international and local interest. The academic papers generated substantial local interest, including attendance by various high school classes at different sessions. The conference itself was opened by the prime minister and the permanent Lapita exhibition, housed at the Vanuatu Cultural Centre (VCC), prepared to coincide with the conference, was opened to the public on the same night. A Lapita Arts Competition was also organised, with various categories from children to adults being enthusiastically supported with dozens of entries in all categories. It was also during this conference that George Tasso, originally from Ambrym Island but now living at Teoumaville, $1.5 \mathrm{~km}$ to the north-east of the Teouma site and $15 \mathrm{~km}$ from the capital Port Vila, approached the VCC, requesting assistance to mount a one-day Lapita exhibition at Teoumaville, to educate the people living in the area on the importance of the Teouma Lapita site. Following discussions of the initial proposal in 2015, the single-day festival ultimately morphed into an annual five-day festival that now involves hundreds of participants and thousands of visitors, and coincides with Vanuatu National Culture Day in November. This chapter outlines the development of this Lapita Festival and the importance it has had in connecting communities to their ancient past and how it has helped make traditional practices relevant to the social challenges of today. The festival has also had other spinoffs, including its connection to a major Pacific sporting event and the discovery of another potential Lapita site in the Teouma valley.

\section{Lapita in Vanuatu}

During the entire period of focused Lapita research since 2000, the VCC, guided by its research policy, has been running an active program of increasing public awareness and participation in relation to archaeology. This has involved such activities as running training workshops for VCC staff and the network of volunteer fieldworkers or filwokas spread throughout the country who are affiliated with the VCC; guiding school tours of excavations, often including some level of participation; mounting exhibitions; producing a range of publications (booklets, posters and comic books) in the three national languages; and regular features on national television and radio and articles in newspapers (Bedford et al. 2011; Shing 2013).

The training workshops, which are integrated into the research excavations, have proved to be particularly successful in terms of raising awareness and the understanding of archaeological sites. The participation over many years of the men and women VCC filwokas greatly facilitated the much wider dissemination of archaeological information and awareness. Among their many other roles, filwokas play a crucial liaison role between foreign researchers and local communities, and, in this regard, are able to explain what archaeological work entails and its aims and values. 
After participating in the workshops, all trainees became fully conversant with the processes involved in archaeological work and were able to explain them to their home communities, who sometimes confuse archaeology with mineral exploration activities. Filwokas are an archipelagowide network of VCC representatives who, having participated in archaeological training workshops, can relay information on the appearance of archaeological remains uncovered during local village activities or larger development projects. It was of course through just such a training program that the Teouma Lapita site was ultimately found (Bedford et al. 2004). Heightened awareness among local communities also aided in adding other Lapita sites, including the recent case of Anelcauhat on Aneityum (Bedford et al. 2016).

\section{Lapita at Teouma}

The story of the serendipitous sequence of events that led to the discovery of the Teouma Lapita site has been detailed elsewhere (Bedford et al. 2004, 2011), but we emphasise here again the key role that the annual training workshops had in finding the site. Salkon Yona, a VCC filwoka from Epi Island, had participated in the workshop of 2003 in August, at the Arapus site on the west coast of Efate. Here he learnt about pottery in general and what Lapita was and how it could be distinguished from other earthenware. Later in 2003, while still in Port Vila on Efate, he discussed the workshop with fellow Epi Islanders. Charlie Nati, who had worked as a bulldozer driver constructing the Teouma Prawn farm, said he had souvenired a large piece of pottery while digging at Teouma. Yona correctly identified the large sherd as being Lapita and contacted the VCC in December. The large single, well-preserved, highly decorated piece caused much excitement at the VCC, but an initial excursion to the area did not find the site. A revisit to the area in early 2004 located the Lapita site (Bedford et al. 2004), and subsequent excavations began in mid-2004.

Collaborative excavations run jointly by The Australian National University and the Vanuatu Cultural Centre ran from 2004 to 2010. Key members of the team from the Vanuatu Cultural Centre comprised Martha Kaltal, the Manager of the Vanuatu Cultural Historical Sites Survey (VCHSS), Willie Damelip, VCHSS Field Officer, Fidel Yoringmal, artist and illustrator and Richard Shing, VCHSS Field Officer. The team was later joined by Iarowai Philip, who worked on shell analysis and on sorting out and joining the thousands of pot sherds excavated over the eight years, and Makaras Longga, who assisted in sorting artefacts and data entry. The VCC filwoka from the nearby village, Silas Alban, was key in encouraging the local community to participate in the excavations and to provide food and lodging for the excavating team and security for the site.

The spectacular nature of the site, with its many burials and whole Lapita pots, and its location only 15 minutes from the capital Port Vila, provided an unprecedented opportunity to the VCC to promote Lapita and archaeology to the wider Vanuatu community. Over the many seasons we ultimately had thousands of school children visiting the site, as well as hundreds of members of the public, including government ministers and even the President of the Republic. Local and international media including radio, newspapers and television couldn't seem to get enough of the news coming from the site. Its fame spread and during a visit to Vanuatu for a conference on Pacific Museums in 2008, Stéphane Martin, the Director of the Musée du Quai Branly in Paris, after touring the VCC and seeing the pottery from the excavations, floated the idea of a Lapita exhibition at his institution.

In 2010, the 'floated idea' became a reality and the Lapita: Oceanic Ancestors exhibition was opened at the Musée du Quai Branly in November and lasted for three months. It was a collaborative effort between the VCC, the Institute of Archaeology for New Caledonia and the Pacific, and the Musée du Quai Branly. It was the largest Lapita exhibition ever held and it not 
only had archaeological materials from New Caledonia and Vanuatu, but it also included Lapita materials from other areas of the Pacific. While a major academic publication was produced (Sand and Bedford 2010) for the exhibition, it was clear that the wider Vanuatu community were unlikely to see either the exhibition or the academic publication, so the VCC thought that a booklet should be produced for local dissemination. The 50-page booklet, titled Lapita Peoples/ Peuples/Pipol (Bedford et al. 2010a), in the three official Vanuatu languages, was printed and two copies were distributed to every school in Vanuatu. On subsequent fieldtrips throughout the archipelago we have regularly encountered teachers and students who are familiar with Lapita through the distribution of the booklet.

Over the years, studies undertaken on various aspects of the Teouma site have provided vital details on the lives of these pioneering communities, including the chronology (Petchey et al. 2015) and direction of settlement, levels of inter-connectivity across the region (Dickinson et al. 2013; Reepmeyer et al. 2010), a range of cultural practices (Bedford et al. 2010b), health and diet (Buckley 2007; Buckley et al. 2008; Kinaston et al. 2014; Valentin et al. 2010, 2014) and impacts on the environment. The discovery of a range of extinct species at the site such as flightless birds (Worthy et al. 2015), land crocodiles (Hawkins 2015) and tortoises (White et al. 2010) particularly provides pause for thought on issues associated with resource management. One of the very important aspects of this research to the contemporary community is that it is relatively easy to relate the results directly to contemporary issues in Vanuatu-that is, environmental management, health, diet and food security. The spectacular 3000-year history of Ni-Vanuatu has begun to be revealed through archaeological research, and it can be used to highlight the fact that for much of the archipelago's history it was customary local practices that sustained the population.

\section{Teouma Lapita Festival}

In the early days of the Lapita discovery in Teouma, only a handful of people outside the field of archaeology could grasp the importance of this site. One such person was George Tasso, a resident of nearby Teoumaville, who was completely inspired by the findings and the site. He immediately started to think about ways to educate the residents of Teoumaville about Lapita and its importance to Vanuatu's cultural heritage. His initial strategy was very low-key and standard practice across the islands: he gathered information on the site and began disseminating it in the local kava bars of the area.

The Eighth Lapita Conference, held in Port Vila in 2015, provided Tasso with further inspiration. He approached the Vanuatu Cultural Centre to assist in a one-day Lapita exhibition to be held at Teoumaville, to educate the people living in the area on the importance of the Teouma Lapita site. After numerous discussions with the Teouma community, it was decided that a festival would be held instead, that it would be for five days, become an annual festival, and that it would coincide with the National Culture Day, on 5 November. The festival would be a time to educate the people of Teouma and the wider public on the findings made at the Teouma Lapita site, the analysis of these findings and what we can learn from them today.

Although most Ni-Vanuatu have heard about the Lapita people and the decorative pots they produced, a great proportion of the population do not understand the significance of the Teouma site and its wider implications. It is for this reason that the Lapita Festival was created. It was anticipated that the theme of the festival would change annually so as to focus on different aspects of the Lapita Cultural Complex and to expand on the knowledge of Lapita, to educate the public at large that Lapita was not just a group of people who made decorative pots but also had a way of life that could be connected with communities today. 
The purposes of the Lapita Festival were to:

- Expand the public's understanding of Lapita; promote the importance of the Lapita culture, not just the elaborately decorated pots but also about their way of life and the connections and relevance for us today; demonstrate that they were knowledgeable, skilful and contributed greatly to Vanuatu's and the region's history; and disseminate information gleaned from the analysis of artefacts and floral and faunal remains from the Teouma Lapita cemetery.

- Promote the significance of the Teouma site and the role it plays in shedding light on the Lapita Cultural Complex, so that the community can take pride in the area they are living in.

- Promote Vanuatu's diverse cultures through various aspects of Lapita culture. An example is by linking the Lapita diet, derived from analysis made on skeletal and faunal remains, to current local traditional dishes, in order to promote our traditional food culture; or raising awareness of the navigational skills inherited from the Lapita people, which are still found in small pockets of the Pacific, to promote the significance of canoes in our culture.

- Empower youth with the organisational and planning skills and collaborating with external partners and stakeholders in organising community-oriented cultural festivals and activities.

- Incorporate cultural knowledge, traditions, practices and activities into the festival to promote, preserve and, as a result, protect the cultural heritage of Vanuatu, aligning with the mission statement of the Vanuatu Cultural Centre.

\section{Lapita Festival 2015}

The first edition of the festival held in November 2015 was themed 'Empowering youth with the knowledge of the past'. Invitations to participate in the event were also extended to the Environment and Climate Change Units of the national government, as they had also carried out studies in the general area and could relate to Lapita research themes. Their participation could help to enlighten the public on the type of environment that welcomed the Lapita people to these shores, thus giving a much more in-depth understanding of the wider setting.

With this in mind, the organising committee consisting of VCC staff, led by the archaeology section, in collaboration with Teouma community youth, planned the festival. A wide range of activities were designed to attract the general public to the event and at the same time educate them on Lapita and its significance to Vanuatu's cultural heritage.

Activities that were used to attract the public and help disseminate information were:

- Exhibitions-booths included the Lapita exhibition and environmental information.

- Stalls_-food and kava stalls to support the community.

- Music-to attract audiences to the festival.

- Sports—also to attract audiences, especially the youth and sportsmen and women.

- Traditional activities, including food preparation and customary dances.

The promotion for the festival was done through social media such as Facebook, and more traditional media such as posters, radio programs and kava bar conversations.

The Teoumaville location for the festival was particularly successful, the five-day communityinspired event being held and run by the community away from the normal conference centres in town. Youth were one of the main target audiences, and so a day was set aside for students to attend the event. During that day, schools were invited to take part, questions were asked on Lapita and prizes were given to encourage students to learn more about Lapita. 
The festival saw huge interest with a lot of questions being asked at the exhibition booths, radio programs (particularly a talkback show) and Q and A sessions after presentations on Lapita. The questions displayed a keen interest from the public to learn more about Lapita and they were particularly inspired to find out that the Lapita story has pushed their history back 3000 years. Questions that were frequently asked were mostly related to evidence of the people themselves, where they were found, how they had been buried, what they ate, what they looked like and of course if they were the ancestors of indigenous $\mathrm{Ni}$-Vanuatu.

\section{Lapita Festival 2016}

The Lapita Festival of 2016 marked the second week-long edition of this new, but promising, event, which aims to promote knowledge and information about the Lapita people and their way of life. In 2016 the theme was 'Healthy youth, healthy future: looking to Lapita for inspiration'. The purpose was to focus on the Lapita diet but in a much more contemporary applicable sense: that of the importance of traditional foods in combating the high number of non-communicable diseases affecting the country. By using this theme, we were able to highlight the Lapita diet of 3000 years ago, the food resources that were readily available to the first settlers of the islands, how they adapted over the generations and how this related to their health (Figure 22.1).

With the festival gaining popularity from its previous edition, the live radio program promotion leading up to the 2016 festival was very active, with callers asking questions and giving both positive and negative comments on the event. Some even called to say what they learnt from the previous event and encouraged others to attend the next one. The late president, His Excellency the Honourable Baldwin Lonsdale, presented the keynote address and made the official launch of festivities for 2016 at the newly designated Don Paterson Lapita Park only $3 \mathrm{~km}$ from the Teouma Lapita site. In 2016 we also launched a new aspect to the festival-the Lapita Voyaging and Way Finding Project. As our ancestors were great seafarers who travelled long distances using traditional canoes and navigational skills, it seemed appropriate to highlight these traditional skills at a time when expensive modern replacements have come to dominate. Members of the Futunese community living in Port Vila made a canoe for the event and it was launched in Teouma Bay (Figure 22.2).

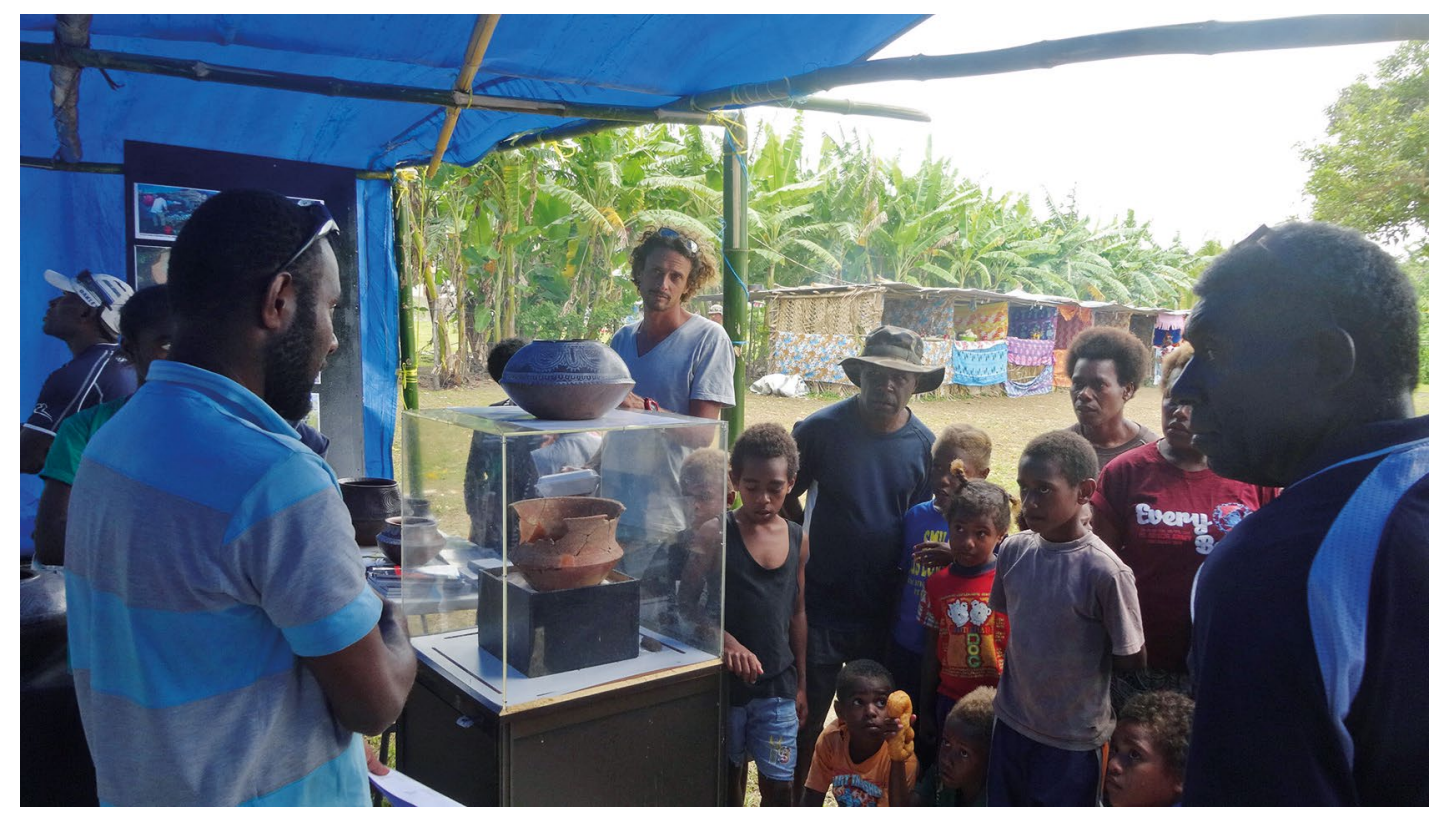

Figure 22.1. Lapita Festival 2016. Makaras Longga on the left discusses Lapita with visitors. Source: Iarowai Philip.

\section{terra australis 52}




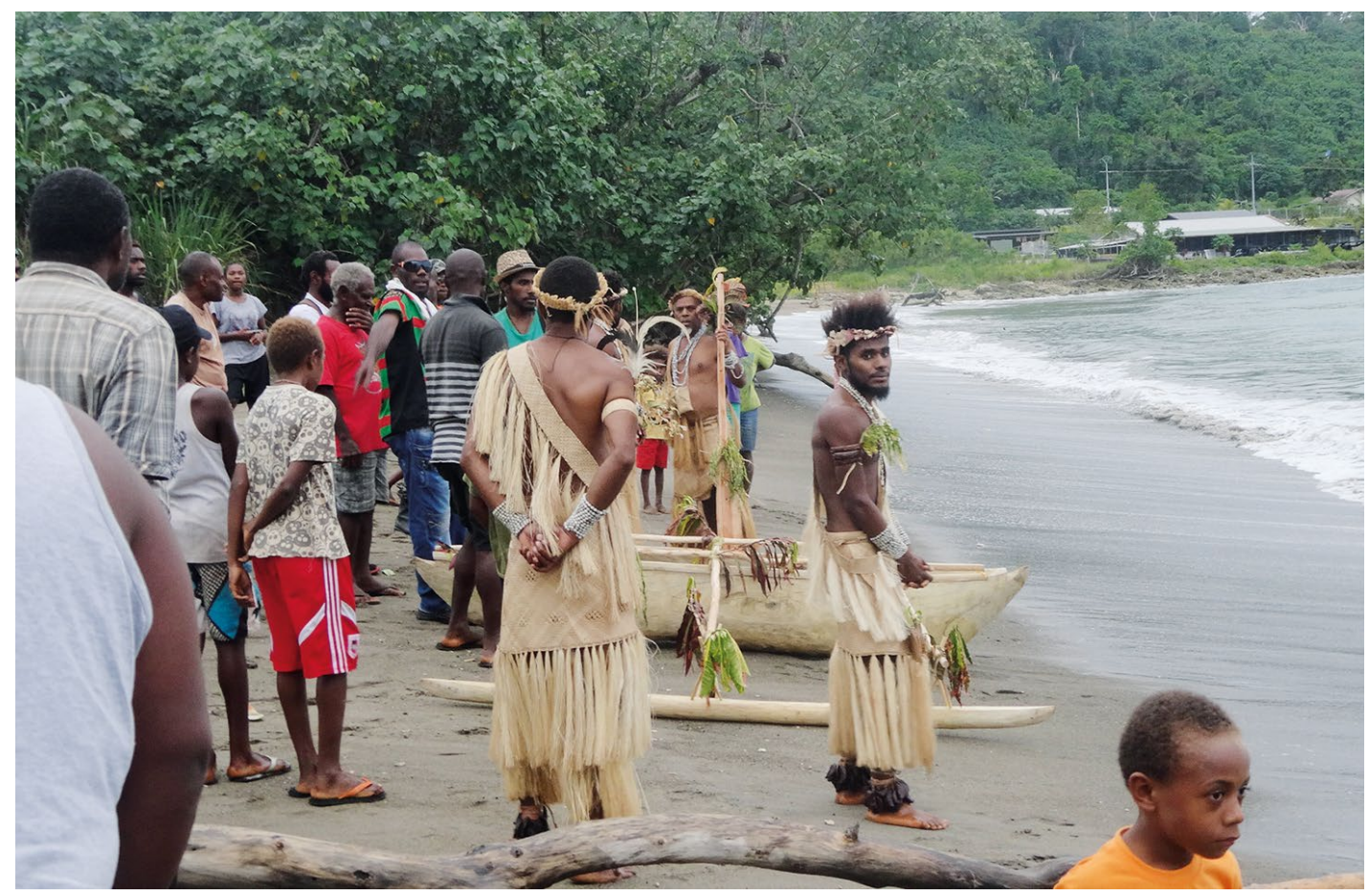

Figure 22.2. Lapita Festival 2016. Members of the Futunese community launch a canoe at Teouma Bay as part of the festivities.

Source: Iarowai Philip.

\section{New discovery}

During the 2016 Lapita Festival, many people from Teouma and the surrounding area visited the festival and the Lapita exhibit. Towards the end of the festival, an elder from the nearby village of Eratap, Mr Api Malesu, approached VCC staff with a piece of Lapita pottery that he had found in his garden on the western side of the Teouma valley. The sherd has elaborate Lapita dentate markings on the exterior and inner rim and appears to be originally part of a flat-bottomed dish (Figure 22.3). The discovery of this new Lapita site across the valley from the famous Lapita cemetery in the Teouma valley is a consequence of the

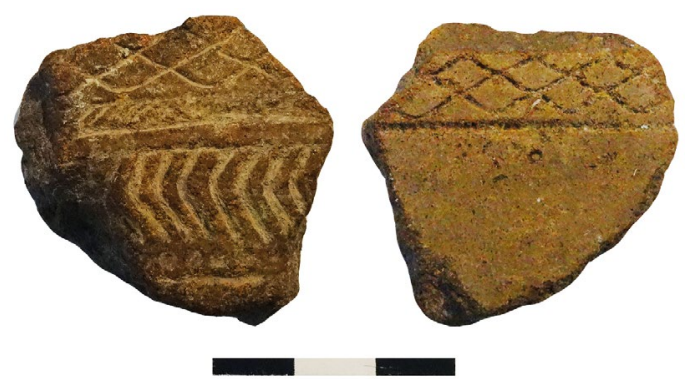

Figure 22.3. Lapita sherd presented by Api Malesu at the Teouma Festival of 2016, collected from the western side of the Teouma valley.

Left is exterior and right is interior of rim sherd from a flat dish. Source: Stuart Bedford. Lapita awareness programs carried out by the VCC and the Teouma Lapita Festival. Preliminary investigations have been carried out at the location of the find, but as yet no site has been identified. Despite not finding any Lapita pottery on the site, the site lies directly opposite the valley from the Teouma Lapita cemetery, which makes it highly likely that there may be a Lapita site there. Further investigations are planned for the future. 


\section{Pacific Mini Games and Lapita Festival 2017}

The third edition of the Lapita Festival in 2017 saw a great boost in the event's profile as it was an integral part of the 10th Pacific Mini Games, Van2017, held in Port Vila from 4 to 15 December (Figure 22.4). The Van2017 Committee decided to host a mini arts festival during the games, which would be organised by the VCC. The VCC, after discussions with the Teouma community, decided to hand the program to a Lapita Festival Committee consisting of the Teouma community and the staff of VCC, again led by the Archaeology Unit team. Instead of having the annual Lapita Festival in the month of November, it was held in December, to take advantage of this high-profile event to promote the knowledge of Lapita and show how research carried out by archaeologists has helped to shed light on the origins of Pacific peoples. A majority of the 24 participating countries at the Mini Games, which included Melanesians, Polynesians and Micronesians, have links in one way or another with the Lapita people and their movement into the Pacific 3000 years ago. Lapita motifs gleaned from those found at Teouma were used on wide range of Van2017 merchandise, including the medals (gold, silver, bronze), the stage (Figure 22.5), the Mini Games baton and the banners naming various countries used in the opening parade.

The Lapita Festival 2017 consisted of a Lapita exhibition that showcased migration of the Lapita people throughout Near and Remote Oceania. The exhibition had on display photos of different Lapita pots found across the Pacific and information on the Lapita culture, including artefacts and cultural materials associated with Lapita research throughout the Pacific with an emphasis on the Teouma site. The Archaeology Unit of the Vanuatu Cultural Centre saw this as a very good opportunity to highlight the important role that the field of archaeology plays in uncovering and preserving cultural heritage.

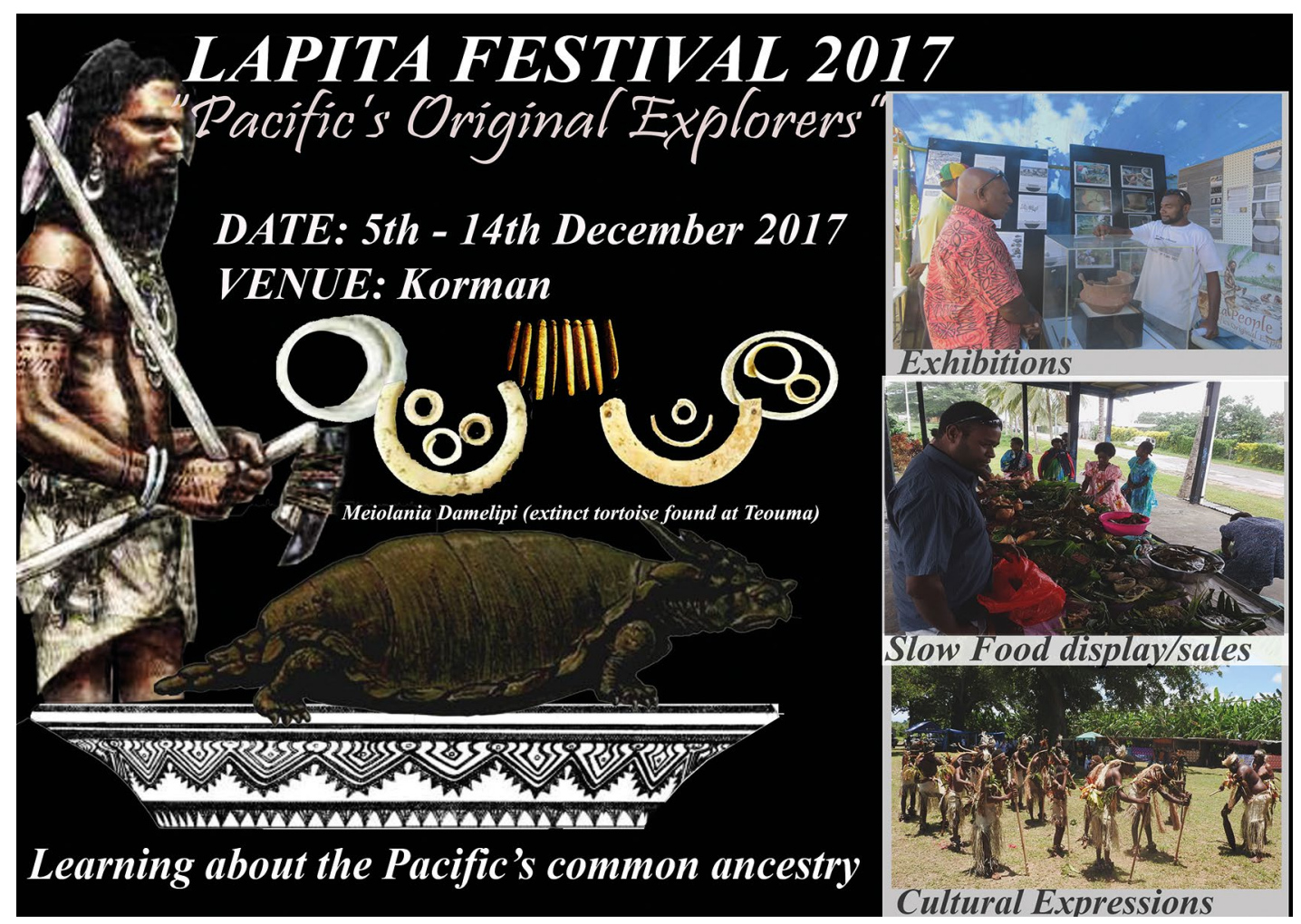

Figure 22.4. Lapita Festival 2017 publicity poster.

Source: Richard Shing. 


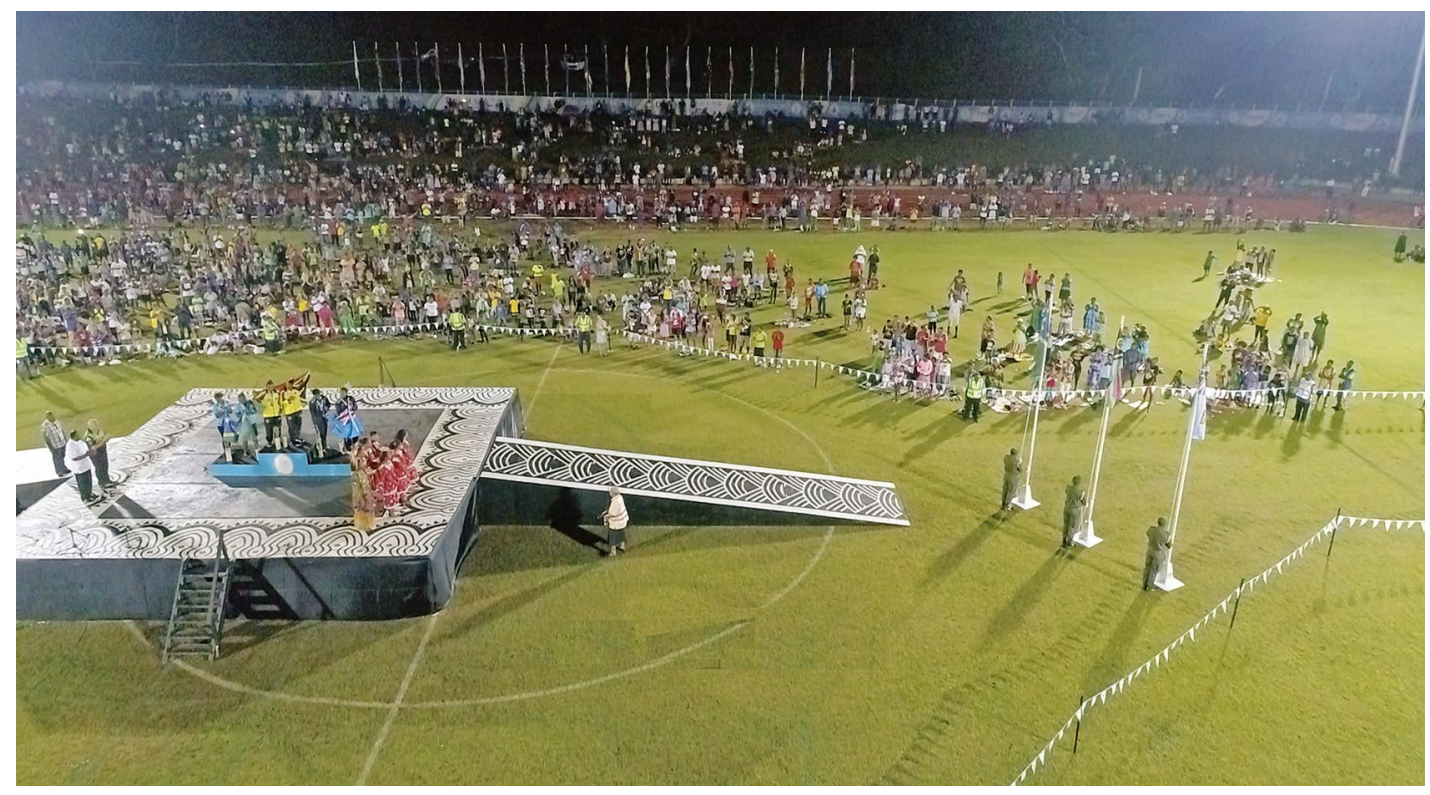

Figure 22.5. Aerial photo of the 10th Pacific Mini Games stage in centre field during a medal ceremony. Lapita motifs, completed by Siri Seoule of the VCC, surround the stage and cover the access ramps.

Source: Mark Lowen.

Traditional knowledge and expressions of culture were also introduced into the festival to promote and help encourage the preservation of the traditional cultures of Vanuatu, many of which are under increasing threat from external influences. Weaving, carving, custom dances and performances and traditional food dishes were displayed for the promotion of Vanuatu's rich cultural heritage. With the Lapita Festival having been incorporated into the 10th Pacific Mini Games, it was hoped that the festival would increase awareness of Lapita in the other countries outside Vanuatu, so that the broader region becomes aware of this event and its importance in understanding the origins of the Pacific people.

\section{Conclusion}

Archaeology is a relatively new field of research in Vanuatu, but the remarkable discoveries to date are slowly gaining momentum and giving credence to the investigation and analysis of the prehistory of Pacific peoples. The findings at Teouma, and in other parts of Vanuatu, have contributed significantly to the knowledge we have today on these initial settlers of the southwest Pacific Islands. Most of the literature on the Lapita findings and the subsequent analyses are in academic jargon that most people would find hard to understand. To attain a wider public recognition of the importance of archaeology, and the contribution it has made in research into Lapita and the contribution to the study of Pacific prehistory, there is a great need for publications and events targeting the general population, especially those with limited formal education. Since it began in 2015, the Lapita Festival has seen an increase in general public awareness about Lapita and its importance to understanding the country's history. Lapita motifs are now seen widely around Vanuatu on clothing, tattoos, decorations on buses and recently they have appeared on the newly launched VT500 banknote. Lapita is also a constant reminder for the population that while we may be a relatively young nation, celebrating only 38 years of independence in 2018, we have a history that stretches back over three millennia (Shing 2013:196, Figure 7). 


\section{References}

Bedford, S. 2003. The timing and nature of Lapita colonisation in Vanuatu: The haze begins to clear. In C. Sand (ed.), Pacific archaeology: Assessments and prospects. Proceedings of the conference for the 50th anniversary of the first Lapita excavation, Kone-Nouméa, 2002, pp. 147-158. Les cahiers de l'archéologie en Nouvelle-Calédonie 15. Département Archéologie, Service des Musées et du Patrimoine de Nouvelle-Calédonie, Nouméa.

Bedford, S. 2006. Pieces of the Vanuatu puzzle: Archaeology of the north, south and centre. Terra Australis 23. Pandanus Books, The Australian National University, Canberra. doi.org/10.22459/PVP.02.2007.

Bedford, S. and M. Spriggs 2014. The archaeology of Vanuatu: 3000 years of history across islands of ash and coral. In E. Cochrane and T. Hunt (eds), The Oxford handbook of prehistoric Oceania. Oxford University Press, Oxford. doi.org/10.1093/oxfordhb/9780199925070.013.015.

Bedford, S., A. Hoffman, M. Kaltal, R. Regenvanu and R. Shing 2004. Dentate-stamped Lapita reappears on Efate, central Vanuatu: A four-decade long drought is broken. Archaeology in New Zealand 47(4):39-49.

Bedford, S., C. Sand and R. Shing 2010a. Lapita peoples/peuples/pipol: Oceanic ancestors/Ancêtres Océaniens/Bubu blong ol man long Pasifik. Vanuatu Cultural Centre, Port Vila.

Bedford, S., M. Spriggs, H. Buckley, F. Valentin, R. Regenvanu and M. Abong 2010b. A cemetery of first settlement: The site of Teouma, South Efate, Vanuatu. In C. Sand and S. Bedford (eds), Lapita: Ancêtres Océaniens/Oceanic ancestors, pp. 140-161. Musée du quai Branly and Somogy, Paris.

Bedford, S., M. Spriggs, R. Regenvanu and S. Yona. 2011. Olfala histri wea i stap andanit long graon: Archaeological training workshops in Vanuatu; a profile, the benefits, spin-offs and extraordinary discoveries. In N. Thieberger and J. Taylor (eds), Working together: Vanuatu research histories, collaborations, projects and reflections, pp. 191-213. ANU E Press, Canberra. doi.org/10.22459/ WTV.10.2011.22.

Bedford, S., M. Spriggs and R. Shing 2016. 'By all means let us complete the exercise': The 50-year search for Lapita on Aneityum, southern Vanuatu and implications for other 'gaps' in the Lapita distribution. Archaeology in Oceania 51:122-130. doi.org/10.1002/arco.5100.

Buckley, H. 2007. Possible gouty arthritis in Lapita-associated skeletons from Teouma, Efate Island, Central Vanuatu. Current Anthropology 48(5):741-749. doi.org/10.1086/520967.

Buckley, H., N. Tayles, M. Spriggs and S. Bedford 2008. A preliminary report on health and disease in Early Lapita skeletons, Vanuatu: Possible biological costs of island colonization. Journal of Island and Coastal Archaeology 3(1):87-114. doi.org/10.1080/15564890801928300.

Dickinson, W.R., S. Bedford and M. Spriggs 2013. Petrography of temper sands in 112 reconstructed Lapita pottery vessels from Teouma (Efate): Archaeological implications and relations to other Vanuatu tempers. Journal of Pacific Archaeology 4(2):1-20.

Hawkins, S. 2015. Human behavioural ecology, anthropogenic impact and subsistence change at the Teouma Lapita site, central Vanuatu, 3000-2500 BP. Unpublished PhD thesis, The Australian National University, Canberra.

Hébert, B. 1965. Nouvelles-Hébrides. Contribution à l'étude archeologique de l'Île Éfaté et des Îles Avoisantes. Études Mélanésiennes 18-20:71-98.

Hedrick, J. and M.E. Shutler 1969. Report on 'Lapita Style' pottery from Malo Island, Northern New Hebrides. Journal of the Polynesian Society 78(2):262-65. 
Kinaston, R., H. Buckley, F. Valentin, S. Bedford, M. Spriggs, S. Hawkins and E. Herrscher 2014. Lapita diet in Remote Oceania: New stable isotope evidence from the 3000-year-old Teouma site, Efate Island, Vanuatu. PLoS ONE 9(3):e90376. doi.org/10.1371/journal.pone.0090376.

Noury, A. and J.-C. Galipaud 2011. Les Lapita: Nomades du Pacifique. IRD Éditions, Marseille. doi.org/ 10.4000/books.irdeditions.653.

Petchey, F., M. Spriggs, S. Bedford and F. Valentin 2015. The chronology of occupation at Teouma, Vanuatu: Use of a modified chronometric hygiene protocol and Bayesian modeling to evaluate midden remains. Journal of Archaeological Science: Reports 4:95-105. doi.org/10.1016/j.jasrep.2015.08.024.

Reepmeyer, C., M. Spriggs, S. Bedford and W. Ambrose 2010. Provenance and technology of lithic artifacts from the Teouma Lapita Site, Vanuatu. Asian Perspectives 49(1):205-225. doi.org/10.1353/ asi.2010.0004.

Sand, C. and S. Bedford 2010. Lapita: Ancêtres Océaniens/Oceanic ancestors. Museé du quai Branly and Somogy, Paris.

Shing, R. 2013. Spreading the word: Archaeological awareness and the wider public in Vanuatu. In G. Summerhayes and H. Buckley (eds), Pacific archaeology: Documenting the past 50,000 years, pp. 189197. Otago University Publications in Archaeology 25, Dunedin.

Valentin, F., H. Buckley, E. Herrscher, R. Kinaston, S. Bedford, M. Spriggs, S. Hawkins and K. Neal 2010. Lapita subsistence strategies and food consumption patterns in the community of Teouma (Efate, Vanuatu). Journal of Archaeological Science 37(8):1820-1829. doi.org/10.1016/j.jas.2010.01.039.

Valentin, F., E. Herrscher, S. Bedford, M. Spriggs and H. Buckley. 2014. Evidence for social and cultural change in central Vanuatu between 3000 and 2000 BP: Comparing funerary and dietary patterns of the first and later generations at Teouma, Efate. The Journal of Island and Coastal Archaeology 9:3:381-399. doi.org/10.1080/15564894.2014.921958.

White, A., T. Worthy, S. Hawkins, S. Bedford and M. Spriggs 2010. Megafaunal meiolaniid horned turtles survived until early human settlement in Vanuatu, Southwest Pacific. Proceedings of the National Academy of Science 107(35):15512-15516. doi.org/10.1073/pnas.1005780107.

Worthy, T., S. Hawkins, S. Bedford and M. Spriggs 2015. Avifauna from the Teouma Lapita site, Efate Island, Vanuatu, including a new genus and species of megapode. Pacific Science 69(2):205254. doi.org/10.2984/69.2.6. 
This text is taken from Debating Lapita: Distribution, Chronology, Society and Subsistence, edited by Stuart Bedford and Matthew Spriggs, published 2019 by ANU Press,

The Australian National University, Canberra, Australia.

doi.org/10.22459/TA52.2019.22 